\title{
The removal of noradrenaline in the pulmonary circulation of rat isolated lungs
}

\author{
VALERIE A. ALABASTER AND Y. S. BAKHLE
}

Department of Pharmacology, Institute of Basic Medical Sciences, Royal College of Surgeons of England, Lincoln's Inn Fields, London WC2A 3PN

\section{Summary}

1. Removal of noradrenaline by isolated lungs of the rat, perfused via the pulmonary artery with Krebs bicarbonate solution has been studied.

2. A constant removal $(40 \cdot 2 \%)$ was observed over a concentration range of 2-50 $\mathrm{ng}$ noradrenaline/ml (12-300 $\mathrm{nM})$. At $100 \mathrm{ng} / \mathrm{ml}(600 \mathrm{nM})$, the removal is significantly reduced to $33 \cdot 5 \%$.

3. The removal of noradrenaline was inhibited by cocaine $(1 \mu \mathrm{M})$, but not by normetanephrine $(5 \mu \mathrm{M})$, metaraminol $(10 \mu \mathrm{M})$, phenoxybenzamine $(10 \mu \mathrm{M})$ and 5-hydroxytryptamine (110 and $560 \mathrm{nM}$ ).

4. We conclude that the removal of noradrenaline in the lungs does not involve an uptake process comparable with those previously described for this amine. The uptake process for noradrenaline in the lung is similar to that for 5-hydroxytryptamine and may be unique to this tissue.

\section{Introduction}

Noradrenaline is inactivated in vivo in the pulmonary circulation of man (Boileau, Campeau \& Biron, 1969) and animals (Ginn \& Vane, 1968 ; Boileau, et al., 1969) and also in isolated lungs perfused with blood (Eiseman, Bryant \& Waltuch, 1964). Hughes, Gillis \& Bloom (1969) found that rat isolated lungs take up and metabolize noradrenaline. We wanted to study the removal of noradrenaline in rat lung so that we could compare it with the removal of 5-hydroxytryptamine (5-HT) in this tissue (Alabaster \& Bakhle, 1970), and with catecholamine uptake processes present in other organs.

\section{Methods}

Rat isolated lungs perfused with warmed $\left(37^{\circ} \mathrm{C}\right)$ and oxygenated $\left(95 \% \mathrm{O}_{2} ; 5 \%\right.$ $\mathrm{CO}_{2}$ ) Krebs bicarbonate solution were prepared as described previously (Alabaster \& Bakhle, 1970). The Krebs bicarbonate solution had the following composition (mM): $\mathrm{NaHCO}_{3}, 25 ; \mathrm{NaCl}, 120 ; \mathrm{KCl}, 4.7 ; \mathrm{CaCl}_{2}, 2.5 ; \mathrm{KH}_{2} \mathrm{PO}_{4}, 1.2 ; \mathrm{MgSO}_{4}, 1.2$; glucose, $5 \cdot 6$. The Krebs solution was pumped through the pulmonary circulation at $8 \mathrm{ml} / \mathrm{min}$ and the effluent from the lung superfused the assay tissues arranged in series. Rat stomach strips (Vane, 1957) were used to detect low concentrations (up to $10 \mathrm{ng} / \mathrm{ml}, 60 \mathrm{nM}$ ) of noradrenaline ; and spiral strips of rabbit aorta (Furchgott \& Bhadrakom, 1953) and strips of the capsular muscle of dog spleen for higher concentrations $(10-100 \mathrm{ng} / \mathrm{ml}, 60-600 \mathrm{nM})$. Spleen strips had the advantage that they relaxed faster than aortic strips after superfusion with noradrenaline. The strips were prepared from spleens taken from dogs used for other experiments. The 
spleen was cut into three or four pieces, stored at $4^{\circ} \mathrm{C}$ overnight and the pieces cut into strips 4-5 cm long and 3-5 $\mathrm{mm}$ wide. The strips were cut parallel to either the long or the short axis of the spleen (circular or longitudinal) and the pulp then scraped off carefully with a sharp scalpel blade. The strips were suspended in the superfusing stream with a load of 1-2 g.

Responses of the assay tissues were recorded by means of auxotonic levers attached to Harvard isotonic muscle transducers and were displayed on a multichannel Watanabe recorder. Perfusion pressure was measured from a side arm in the cannula in the pulmonary artery with a pressure transducer (S.E. Laboratories), and also displayed on the recorder.

The amount of noradrenaline removed by the lungs was determined by comparing the responses of the assay tissues to the amine solution superfused directly over the assay tissues, with responses to the amine solution which had passed through the lung. The infusions were of $4 \mathrm{~min}$ duration allowing the assay tissues to reach a maintained response. The effects of cocaine on the removal of 5-hydroxytryptamine in rat lungs were investigated in similar experiments as described previously (Alabaster \& Bakhle, 1970). The drugs used were: (-)-noradrenaline, cocaine hydrochloride (BDH); ( \pm )-normetanephrine hydrochloride (Calbiochem); metaraminol tartrate (Merck, Sharp \& Dohme); 5-hydroxytryptamine creatinine sulphate (May \& Baker); phenoxybenzamine hydrochloride (Smith, Kline \& French); ( \pm )-propranolol hydrochloride (ICI); phentolamine mesylate (Ciba). Doses are given in molar concentrations or as the weight of base per $\mathrm{ml}$ and refer to the final concentration of the substance.

\section{Results}

The lungs removed about $30-40 \%$ of noradrenaline infused through the pulmonary circulation. The variation of the amount of noradrenaline removed with

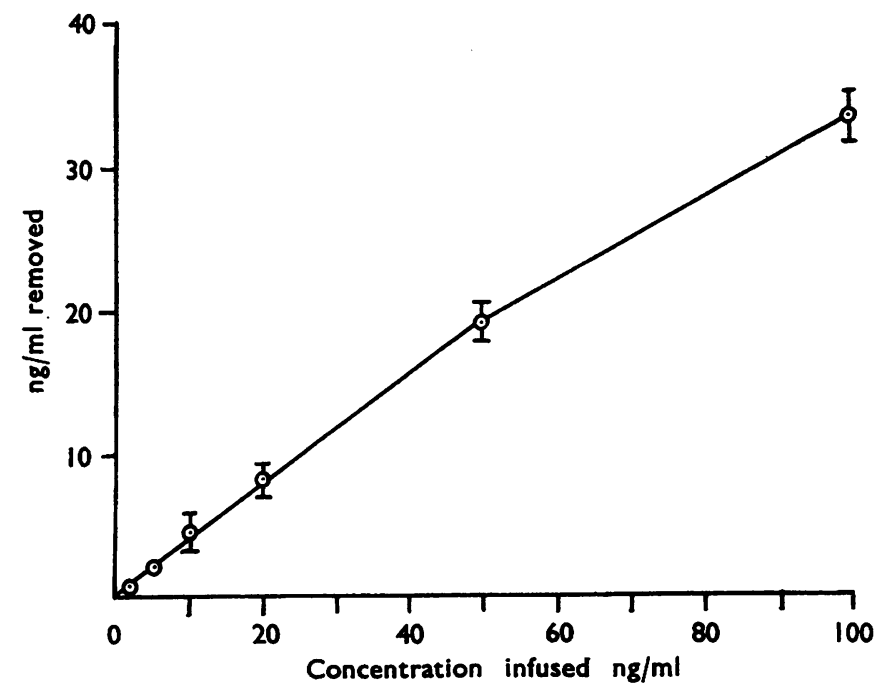

FIG. 1. Noradrenaline removal by rat isolated lungs as a function of the concentration infused. Noradrenaline removed by the lung $(\mathrm{ng} / \mathrm{ml})$ was plotted against the concentration of noradrenaline infused into the pulmonary artery. The vertical bars represent standard errors of the mean when more than 5 experiments were carried out. 
concentration of noradrenaline infused through the lung is shown in Figure 1. The removal at the highest concentration used $(100 \mathrm{ng} / \mathrm{ml})$ was $33 \cdot 5 \pm 1 \cdot 8 \%(n=13)$, significantly lower $(P<0.01)$ than the removal at concentrations up to $50 \mathrm{ng} / \mathrm{ml}$ $(40 \cdot 2 \pm 1 \cdot 4, n=21)$.

Relaxations of the rat stomach strip and contractions of the aortic strip or the spleen strip in response to noradrenaline were abolished by propranolol (40 nM) and phentolamine ( $30 \mathrm{nM})$ respectively. With the three assay tissues described, there was no evidence of biological activity, other than that due to noradrenaline, in the effluent from the lung during infusions of noradrenaline into the pulmonary circulation.

Over the whole range of noradrenaline concentrations $(2 \cdot 0-100 \mathrm{ng} / \mathrm{ml}, 12-600$ $\mathrm{nM}$ ), perfusion pressure never increased more than $6 \mathrm{mmHg}$ during an infusion of noradrenaline through the lung.

\section{Cocaine}

\section{Effect of inhibitors of uptake}

Cocaine $(1 \mu \mathrm{M})$ perfused through the lung reduced the removal of noradrenaline from $33 \%$ to $11 \%$ (Table 1). Responses of the rat stomach strip and the spleen

TABLE 1. Effect of amines, infused through the pulmonary circulation, on the removal of noradrenaline and 5-hydroxytryptamine (5-HT) by rat isolated lungs

Amine (concentration infused)

Control (noradrenaline, $12-60 \mathrm{nM} ; 2-10 \mathrm{ng} / \mathrm{ml}$ )

Phenoxybenzamine $(10 \mu \mathrm{M})$

Control (noradrenaline, $600 \mathrm{nM} ; 100 \mathrm{ng} / \mathrm{ml}$ )

Cocaine $(1 \mu \mathrm{M})$

Normetanephrine $(5 \mu \mathrm{M})$

Metaraminol $(10 \mu \mathrm{M})$

5-HT $(112 \mathrm{nM} ; 20 \mathrm{ng} / \mathrm{ml})$

$(560 \mathrm{nM} ; 100 \mathrm{ng} / \mathrm{ml})$

Control (5-HT, 3-11 nM; 5-20 ng/ml)

Cocaine $(1 \mu \mathrm{M})$

$\begin{array}{cc}\begin{array}{c}\text { \% Removal } \\ \text { mean } \pm \text { S.E.M. }\end{array} & \begin{array}{c}\text { No. of } \\ \text { experiments }\end{array} \\ 41 \cdot 8 \pm 1 \cdot 5 & 10 \\ 42 \cdot 8 \pm 1.9 & 7 \\ 33.5 \pm 1 \cdot 8 & 13 \\ 11.0 \pm 3 \cdot 1^{*} & 5 \\ 37.5 \pm 2.9 & 6 \\ 36.6 \pm 2 \cdot 1 & 6 \\ 34.0 & 2 \\ 31 \cdot 8 & 3 \\ 92.3 \pm 0.3 & 57 \\ 55.3 \pm 5 \cdot 2 * & 6\end{array}$

* These values are significantly $(P<0.01)$ different from their control values using Student's $t$ test.

strip to noradrenaline were potentiated by this concentration of cocaine. These effects are illustrated in Figure 2. Here the effluent from the lungs superfused two spleen strips. Under control conditions, about $35 \%$ of noradrenaline perfused through the lungs was removed, $100 \mathrm{ng} / \mathrm{ml}$ through the lungs being equivalent to about $65 \mathrm{ng} / \mathrm{ml}$ applied directly to the assay tissue. Cocaine $(1 \mu \mathrm{M})$ was then perfused through the lungs and phentolamine ( $30 \mathrm{nM})$ superfused over the lower spleen strip only, and the perfusion of noradrenaline through the lungs repeated. The removal of noradrenaline was almost completely prevented, a concentration of noradrenaline of $100 \mathrm{ng} / \mathrm{ml}$ through the lungs being equivalent to $95 \mathrm{ng} / \mathrm{ml}$ given directly on the upper spleen strip. The lower spleen strip did not contract during this infusion showing that the contraction of the upper strip was entirely due to noradrenaline and not to other active substances released from the lung. The potentiation of responses to noradrenaline given directly in the presence of cocaine was also clearly demonstrated (compare third and last contractions of upper strip). The same concentration of cocaine also reduced the removal of 5-hydroxytryptamine by the lung from $92 \%$ to $55 \%$ (Table 1 , last section). 


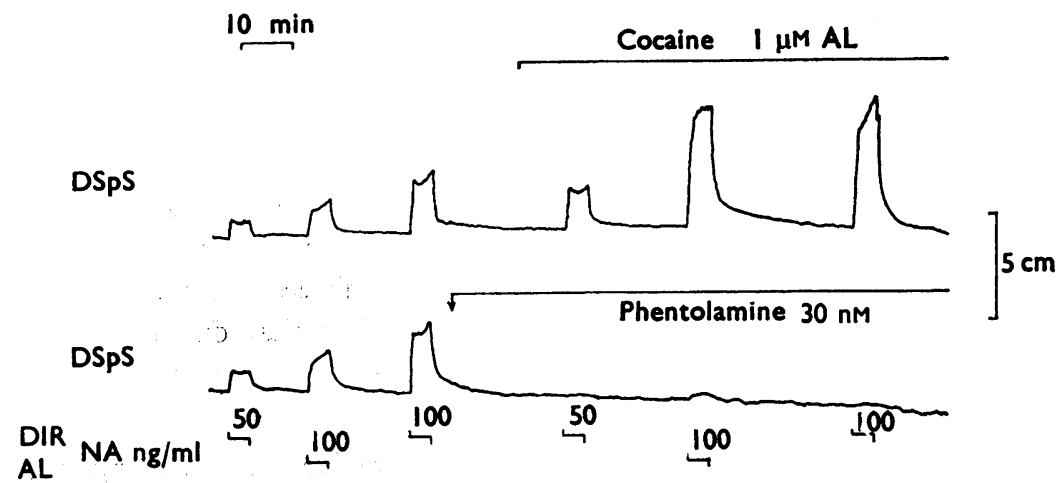

FIG. 2. Effect of cocaine on removal of noradrenaline in rat isolated lungs. The record shows contractions of two dog splenic capsule strips (DSpS) superfused in series with effluent from rat lungs perfused with Krebs solution, to infusions of noradrenaline (NA) given directly to the tissues (DIR) or given into the pulmonary artery cannula (AL). In the untreated lung, removal of noradrenaline was $35 \%$. Cocaine was perfused through the lungs as indicated and noradrenaline removal by the lung was reduced to $4 \%$. Cocaine potentiated the height of responses of the splenic capsule strip to noradrenaline. Phentolamine superfused over the bottom tissue blocked responses to noradrenaline, indicating that contractions of the top tissue were in fact due to noradrenaline and not to substances released from the lung.

\section{Metaraminol, normetanephrine and phenoxybenzamine}

Metaraminol $(10 \mu \mathrm{M})$ and normetanephrine $(5 \mu \mathrm{M})$ perfused through the lung did not affect the removal of noradrenaline $(100 \mathrm{ng} / \mathrm{ml}, 600 \mathrm{nM})$ by rat isolated lung (Table 1), although the former compound potentiated the responses of the spleen strip to noradrenaline by two to four-fold.

Phenoxybenzamine $(10 \mu \mathrm{M})$ perfused through the lung had no effect on the removal of noradrenaline by the lung (Table 1). In these experiments, noradrenaline was assayed on rat stomach strips in which the relaxation of the strips by noradrenaline is mediated through $\beta$-adrenoceptors. In some experiments, phenoxybenzamine potentiated the action of noradrenaline as in that illustrated in Figure 3.

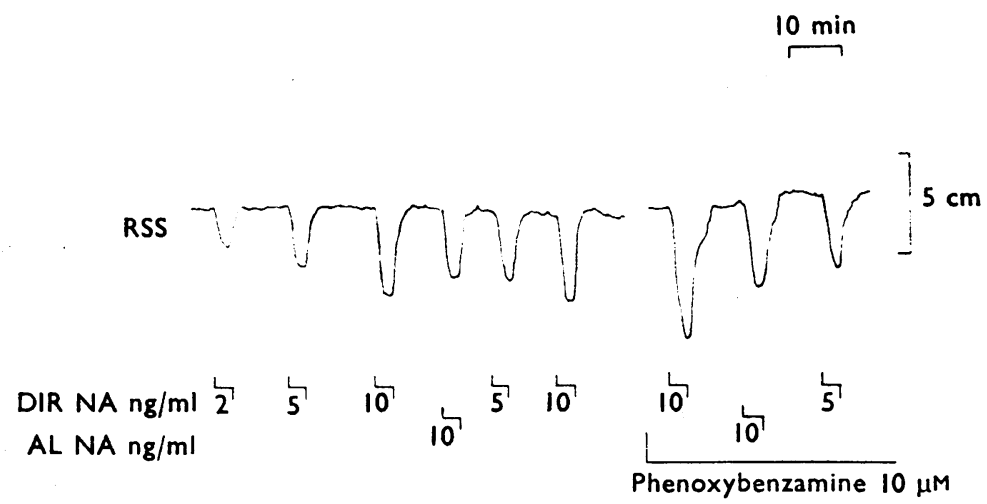

FIG. 3. Effect of phenoxybenzamine on removal of noradrenaline in rat isolated lungs. The record shows the relaxations of a rat stomach strip (RSS), superfused with Krebs solution, in response to infusions of noradrenaline (NA) given directly (DIR) or into the pulmonary artery cannula (AL). In the untreated lung removal of noradrenaline was $46 \%$. Phenoxybenzamine perfused through the lungs as indicated did not reduce lung removal of noradrenaline, although the responses of the tissue were potentiated. 
The effluent from the lung superfused a rat stomach strip and, under control conditions, $46 \%$ of an infusion of noradrenaline $(10 \mathrm{ng} / \mathrm{ml}, 60 \mathrm{nM})$ was removed by the lung. During infusion of phenoxybenzamine $(10 \mu \mathrm{M})$ through the lung, although responses to noradrenaline given directly were potentiated, the removal by the lung was unchanged.

\section{5-Hydroxytryptamine}

In these experiments, the spleen strips were used to assay noradrenaline in the presence of 5-hydroxytryptamine as these tissues do not respond to 5-hydroxytryptamine in the concentrations used. The removal of noradrenaline $(100 \mathrm{ng} / \mathrm{ml}$, $600 \mathrm{nM}$ ) was not affected by the concomitant infusion of 5-hydroxytryptamine $(20-100 \mathrm{ng} / \mathrm{ml}, 112-560 \mathrm{nM})$.

\section{Discussion}

The rat isolated lung removes $30-40 \%$ of the noradrenaline in the perfusion fluid passing through the pulmonary circulation. This result is consistent with the $35 \%$ pulmonary inactivation of noradrenaline in vivo for dogs (Ginn \& Vane, 1968) and with the results of Hughes et al. (1969) for rat isolated lungs. The latter authors measured the amount of noradrenaline retained by the lung after perfusion with Krebs solution containing noradrenaline and deduced that their results were equivalent to a removal of about $30 \%$ for a 5 min perfusion.

One of their crucial findings was that after perfusion of ${ }^{3} \mathrm{H}$-noradrenaline through the untreated lung, only $20 \%$ of the radioactivity retained was present as noradrenaline, the remainder being deaminated and $O$-methylated metabolites. This rapid and extensive metabolism of sequestered amine is also seen with 5-hydroxytryptamine taken up by the lung (Alabaster \& Bakhle, 1970).

We may conclude from the results of Hughes et al. (1969) that the overall removal of noradrenaline by the lung consists of uptake into cells (they suggest capillary endothelial cells) and subsequent metabolism. Thus inhibition of uptake would prevent metabolism and reduce overall removal. Clearly the uptake of noradrenaline by rat isolated lung is not like the intraneuronal Uptake ${ }_{1}$ or the extraneuronal Uptake $_{2}$ (in rat heart and cat spleen) described by Lightman \& Iversen (1969), since both metaraminol, an Uptake ${ }_{1}$ inhibitor, and normetanephrine, an Uptake ${ }_{2}$ inhibitor, did not inhibit the removal in the lung. Phenoxybenzamine reduces the accumulation of extraneuronal noradrenaline in rat heart, vas deferens and cat spleen (Eisenfeld, Landsberg \& Axelrod, 1967 ; Iversen \& Langer, 1969 ; Gillespie, Hamilton \& Hosie, 1970), but this compound does not affect the pulmonary removal of noradrenaline. Nevertheless, the removal and hence uptake is reduced by cocaine, confirming the results of Hughes et al. (1969).

The removal of 5-hydroxytryptamine in the pulmonary circulation of rat lungs is inhibited by cocaine (this paper), amitriptyline, desmethylimipramine and tranylcypromine but is unaffected by normetanephrine, metaraminol, phenoxybenzamine and noradrenaline (Alabaster \& Bakhle, 1970). It is clear, therefore, that the uptake mechanism for noradrenaline in the pulmonary circulation of the rat is more like that of 5-hydroxytryptamine and unlike the previously described mechanisms of catecholamine uptake. We did not investigate the effect of amitriptyline or desmethylimipramine on noradrenaline removal as these compounds in concentrations 
of 1-10 $\mu \mathrm{M}$ severely depressed the responses of the assay tissues to noradrenaline. Tricyclic anti-depressants of the imipramine type are known to have $\alpha$-adrenoceptor blocking activity (Osborne \& Sigg, 1960) and the concentration range between $\alpha$-receptor blockade and catecholamine uptake blockade in some tissues is narrow (Thoenen, Hurlimann \& Haefely, 1964).

There is, however, no evidence of competition for uptake between these two amines although the removal of 5-hydroxytryptamine is three times that of noradrenaline between 10-200 nM. Furthermore, at a concentration at which noradrenaline removal is already submaximal $(100 \mathrm{ng} / \mathrm{ml}, 600 \mathrm{nM})$ suggesting an approach to saturation of the uptake system, 5-hydroxytryptamine is without effect on the removal of noradrenaline. This suggests that the amines have different uptake sites although they share a common uptake mechanism, which may be unique to the pulmonary circulation. It is worth emphasizing that this removal mechanism in the lung operates at low concentrations of amine similar to those at which Uptake $e_{1}$ is predominant and, like Uptake $e_{1}$, it may be a physiologically signifcant process.

Noradrenaline or 5-hydroxytryptamine taken up by the pulmonary circulation is not stored in granules immune from enzymic attack, like that taken up by nervous tissue, platelets, mast cells etc., but is extensively metabolized. This enables the lung to inactivate a continuous supply of these amines and thus exert a continuous control over the pharmacodynamics of these amines in the animal. Furthermore, as pointed out by Vane (1969), the effects of certain inhibitors of amine uptake mechanisms, e.g. cocaine, amitriptyline, on the responses to noradrenaline and 5hydroxytryptamine in the whole animal may be due not only to inhibition of amine uptake in target tissues but also to increased amounts of amine passing into the arterial circulation.

This work was supported by the Medical Research Council. One of us (V. A. A.) thanks the Wellcome Trust for their generous support.

\section{REFERENCES}

Alabaster, Valerie A. \& Bakhle, Y. S. (1970). Removal of 5-hydroxytryptamine in the pulmonary circulation of rat isolated lungs. Br. J. Pharmac., 40, 468-482.

Boileau, J. C., Campeau, L. \& Biron, P. (1969). Norepinephrine inactivation in the pulmonary circulation of animals and humans. Clin. Res., 17, 230.

Eiseman, B., BRYANT, L. \& WALTUCh, T. (1964). Metabolism of vasomotor agents by the isolated perfused lung. J. Thoracic Cardiovasc. Surg., 48, 798-808.

EISENFELD, A. J., LANDSBERG, L. \& AXELROD, J. (1967). Effect of drugs on the accumulation and metabolism of extraneuronal noradrenaline in rat heart. J. Pharmac. exp. Ther., 158, 378-385.

FurChGOTT, R. F. \& BHADRAKom, S. (1953). Reactions of strips of rabbit aorta to epinephrine, isopropylarterenol, sodium nitrite and other drugs. J. Pharmac. exp. Ther., 108, 128-143.

Gillespie, J. S., Hamilton, D. M. H. \& Hosie, R. J. A. (1970). The extraneuronal uptake and localisation of noradrenaline in the cat spleen and the effect on this of some drugs, of cold and of denervation. J. Physiol., Lond., 206, 563-590.

GinN, R. \& VANE, J. R. (1968). The disappearance of catecholamines from the circulation. Nature, Lond., 219, 740-742.

Hughes, J. R., Gillis, C. N. \& Bloom, F. E. (1969). The uptake and disposition of dl-norepinephrine in perfused rat lung. J. Pharm. exp. Ther., 169, 237-248.

IVERSEN, L. L. \& LANGER, S. Z. (1969). Effects of phenoxybenzamine on the uptake and metabolism of noradrenaline in the rat heart and vas deferens. Br.J. Pharmac., 37, 627-637.

Lightman, S. L. \& IVERSEN, L. L. (1969). The role of Uptake in the extraneuronal metabolism of catecholamines in the isolated rat heart. Br. J. Pharmac., 37, 638-649.

OSBORNE, M. \& SigG, E. B. (1960). Effects of imipramine on the peripheral autonomic system. Arch. int. Pharmacodynam., 129, 273-289. 
Thoenen, H., Hurlimann, A. \& Haefely, W. (1964). Mode of action of imipramine and 5-(31methylaminopropylidene)-dibenzo (a; e) cyclohepta $(1,3,5)$ triene hydrochloride (Ro4-6011), a new antidepressant drug, on peripheral adrenergic mechanisms. J. Pharmac. exp. Ther., 144, 405-414.

VANE, J. R. (1957). A sensitive method for the assay of 5-hydroxytryptamine. Br. J. Pharmac. Chemother., 12, 344-349.

VANE, J. R. (1969). The release and fate of vasoactive hormones in the circulation. Br. J. Pharmac., 35, 209-242.

(Received June 28, 1972) 